\title{
Chapter 10 \\ Therapeutic Development and Drugs for the Treatment of COVID-19
}

\author{
Vimal K. Maurya, Swatantra Kumar, Madan L. B. Bhatt, \\ and Shailendra K. Saxena
}

\begin{abstract}
SARS-CoV-2/novel coronavirus (2019-nCoV) is a new strain that has recently been confirmed in Wuhan City, Hubei Province of China, and spreads to more than 165 countries of the world including India. The virus infection leads to 245,922 confirmed cases and 10,048 deaths worldwide as of March 20, 2020. Coronaviruses (CoVs) are lethal zoonotic viruses, highly pathogenic in nature, and responsible for diseases ranging from common cold to severe illness such as Middle East respiratory syndrome (MERS) and severe acute respiratory syndrome (SARS) in humans for the past 15 years. Considering the severity of the current and previous outbreaks, no approved antiviral agent or effective vaccines are present for the prevention and treatment of infection during the epidemics. Although, various molecules have been shown to be effective against coronaviruses both in vitro and in vivo, but the antiviral activities of these molecules are not well established in humans. Therefore, this chapter is planned to provide information about available treatment and preventive measures for the coronavirus infections during outbreaks. This chapter also discusses the possible role of supportive therapy, repurposing drugs, and complementary and alternative medicines for the management of coronaviruses including COVID-19.
\end{abstract}

Keywords SARS-CoV-2 $\cdot$ Novel coronavirus $(2019-n C o V) \cdot$ MERS-CoV $\cdot$ SARS$\mathrm{CoV} \cdot \mathrm{Complementary}$ and alternative medicines $\cdot$ Repurposing drugs

V. K. Maurya $\cdot$ S. Kumar $\cdot$ M. L. B. Bhatt $\cdot$ S. K. Saxena $(\bowtie)$

Department of Centre for Advanced Research (CFAR), Faculty of Medicine, King George's

Medical University (KGMU), Lucknow, India

e-mail: shailen@kgmcindia.edu

(C) The Editor(s) (if applicable) and The Author(s), under exclusive licence to 


\subsection{Introduction}

Coronaviruses (CoVs) are enveloped, positive-sense RNA viruses belonging to the subfamily Coronavirinae and order Nidovirales (Huang et al. 2020). CoVs have a common genome organization and are commonly categorized as alpha CoVs, beta CoVs, gamma CoVs, and delta CoVs on the basis of genomic structures and phylogenetic relationships. In these CoVs, transmission of alpha CoVs and beta $\mathrm{CoVs}$ is restricted to mammals and induces respiratory illness in humans, while gamma CoVs and delta CoVs are known to affect birds and mammals (Song et al. 2019). Even though, most CoV infections are mild, but the outbreaks of the two beta CoVs, i.e., Middle East respiratory syndrome coronavirus (MERS-CoV) and severe acute respiratory syndrome coronavirus (SARS-CoV), have caused more than 10,000 combined cases and 1600 deaths in last 20 years (Skariyachan et al. 2019). The incubation period of MERS and SARS is given as 2-13 and 2-14 days, respectively, the progression of infection is rapid with MERS-CoV as compared to SARS-CoV, and the reported mortality rates were $34 \%$ and $10 \%$, respectively (Chen et al. 2020; Rasmussen et al. 2016). CoVs are zoonotic in nature, which means these viruses are transmitted between animals and humans. In the same way, SARS and MARS were reported to transmit in humans from civet cats and camel, respectively (Shehata et al. 2016). Human-to-human transmission of SARS and MARS is also reported via close personal contact with infected patients. In 2012, MERS emerged as global heath challenge in countries near the Arabian Peninsula. As of July 31, 2019, 2458 laboratory-confirmed MERS cases and 848 deaths were reported where around $80 \%$ of these cases have been reported only in Saudi Arabia (Zheng et al. 2019). In 2003, SARS-CoV was originated in southern China and transmitted to Hong Kong and 29 other countries with high human morbidity, leading to 8098 confirmed cases and 774 deaths (Hui and Zumla 2019).

SARS-CoV-2 has recently been confirmed in Wuhan City, Hubei Province of China, and spreads to more than 165 countries of the world including India (Li et al. 2020). The virus infection leads to 245,922 confirmed cases and 10,048 deaths worldwide as of March 20, 2020 (ProMED-mail 2020). SARS-CoV-2 and SARS are clinically similar, and recent studies have shown that SARS-CoV-2 is closely related to SARS-CoV (Kumar et al. 2020). The cause and spread of SARS-CoV-2 outbreak are still unclear. Preliminary research has found positive samples for $\mathrm{WN}-\mathrm{CoV}$ in the wholesale market of Huanan seafood in Wuhan City, but some patients confirmed by the laboratory have not reported visiting this area (Centers for Diseases Control and Prevention (CDC) 2020). Evidence is still emerging; however, information to date shows that transmission from human to human occurs. SARSCoV-2 infection in patients leads to pneumonia-like symptoms such as fever and difficulty in breathing with radiographs showing invasive pneumonic infiltrates in few cases. The evolution of novel CoVs has been shown to be associated with RNA recombination with the existing CoVs (Andersen et al. 2020). The coronavirus (SARS-CoV-2, MERS, and SARS) infection initially spreads in adults, and the reported symptoms are fever, headache, vomiting, chills, dyspnea, nausea, sore throat, coughing up blood, shortness of breath, myalgia, diarrhea, and malaise (Table 10.1). 
Table 10.1 Epidemiology and characteristics of 2019-nCoV, MERS-CoV and SARS-CoV

\begin{tabular}{|c|c|c|c|}
\hline Characteristics & 2019-nCoV & MERS-CoV & SARS-CoV \\
\hline Genus & Beta-CoVs, lineage B & Beta-CoVs, lineage $C$ & Beta-CoVs, lineage $B$ \\
\hline $\begin{array}{l}\text { Intermediary } \\
\text { host }\end{array}$ & Malayan pangolins & Dromedary camel & Palm civet \\
\hline $\begin{array}{l}\text { Natural } \\
\text { reservoir }\end{array}$ & Bat & Bat & Bat \\
\hline Origin & $\begin{array}{l}\text { Wuhan City, Hubei } \\
\text { Province of China }\end{array}$ & Arabian Peninsula & $\begin{array}{l}\text { Guangdong Province, } \\
\text { China }\end{array}$ \\
\hline $\begin{array}{l}\text { Confirmed } \\
\text { cases }\end{array}$ & $\begin{array}{l}245,922 \text { (as of March } \\
20,2020)\end{array}$ & 2458 (July 31, 2019) & 8098 \\
\hline Total deaths & $\begin{array}{l}10,048 \text { (as of March } \\
20,2020)\end{array}$ & 848 & 774 \\
\hline $\begin{array}{l}\text { Affected } \\
\text { countries }\end{array}$ & $\begin{array}{l}168 \text { (as of March } \\
20,2020)\end{array}$ & 27 & 29 \\
\hline $\begin{array}{l}\text { Transmission } \\
\text { patterns }\end{array}$ & $\begin{array}{l}\text { From animal to human; } \\
\text { from human to human }\end{array}$ & $\begin{array}{l}\text { From animal to human; } \\
\text { from human to human }\end{array}$ & $\begin{array}{l}\text { From animal to human; } \\
\text { from human to human }\end{array}$ \\
\hline $\begin{array}{l}\text { The predomi- } \\
\text { nant receptor }\end{array}$ & $\begin{array}{l}\text { Cellular protease } \\
\text { TMPRSS2 and } \\
\text { angiotensin-converting } \\
\text { enzyme } 2\end{array}$ & $\begin{array}{l}\text { Human dipeptidyl pepti- } \\
\text { dase } 4 \text { (DPP4 or CD26) }\end{array}$ & $\begin{array}{l}\text { Human angiotensin- } \\
\text { converting enzyme } \\
2 \text { (ACE2) }\end{array}$ \\
\hline $\begin{array}{l}\text { Cell line } \\
\text { susceptibility }\end{array}$ & Respiratory tract & $\begin{array}{l}\text { Respiratory tract, intesti- } \\
\text { nal tract, genitourinary } \\
\text { tract, liver, kidney, neu- } \\
\text { rons, monocyte, T lym- } \\
\text { phocyte and histiocytic } \\
\text { cell lines }\end{array}$ & $\begin{array}{l}\text { Respiratory tract; kid- } \\
\text { ney; liver }\end{array}$ \\
\hline $\begin{array}{l}\text { Viral replica- } \\
\text { tion efficiency }\end{array}$ & Very high & High & $\begin{array}{l}\text { Lesser compared to } \\
\text { MERS-CoV }\end{array}$ \\
\hline $\begin{array}{l}\text { Length of } \\
\text { nucleotides }\end{array}$ & 29,891 & 30,119 & 29,727 \\
\hline $\begin{array}{l}\text { Open reading } \\
\text { frames (ORFs) }\end{array}$ & 12 & 11 & 11 \\
\hline $\begin{array}{l}\text { Structural } \\
\text { protein }\end{array}$ & 4 & 4 & 4 \\
\hline $\begin{array}{l}\text { Spike protein } \\
\text { (length of } \\
\text { amino acids) }\end{array}$ & 1273 & 1353 & 1255 \\
\hline $\begin{array}{l}\text { Non-structural } \\
\text { proteins } \\
\text { (NSPs) }\end{array}$ & 16 & 16 & 5 \\
\hline $\begin{array}{l}\text { Accessory } \\
\text { proteins }\end{array}$ & 6 & 5 & 8 \\
\hline $\begin{array}{l}\text { A characteris- } \\
\text { tic gene order }\end{array}$ & $\begin{array}{l}5^{\prime} \text {-Replicase ORF1ab, } \\
\text { spike }(\mathrm{S}), \text { envelope }(\mathrm{E}), \\
\text { membrane }(\mathrm{M}), \text { and } \\
\text { nucleocapsid }(\mathrm{N})-3^{\prime}\end{array}$ & $\begin{array}{l}5^{\prime} \text {-Replicase ORF1ab, } \\
\text { spike }(\mathrm{S}), \text { envelope }(\mathrm{E}), \\
\text { membrane }(\mathrm{M}), \text { and } \\
\text { nucleocapsid }(\mathrm{N})-3^{\prime}\end{array}$ & $\begin{array}{l}5^{\prime} \text {-Replicase ORF1ab, } \\
\text { spike }(\mathrm{S}), \text { envelope }(\mathrm{E}), \\
\text { membrane }(\mathrm{M}), \text { and } \\
\text { nucleocapsid }(\mathrm{N})-3^{\prime}\end{array}$ \\
\hline
\end{tabular}


Severe infection leads to pneumonia, acute respiratory distress syndrome (ARDS), and sometimes multi-organ failure (Paules et al. 2020). Coronavirus infection leads to thrombocytopenia, lymphopenia, and leukopenia with elevated levels of lactate dehydrogenase and liver enzymes (Arabi et al. 2014).

\subsection{Treatment of Novel Coronavirus SARS-CoV-2 Infection}

According to the World Health Organization (WHO), there is no existing data from randomized clinical trials to advocate any specific anti-nCoV therapy for patients either suspected or diagnosed with SARS-CoV-2. Unlicensed treatments can only be given in the circumstance of ethically approved clinical trials or under the Monitored Emergency Use of Unregistered Interventions System (MEURI), with strict supervision (World Health Organization 2020a). However, researchers have tested a number of FDA-approved drugs against SARS-CoV-2 infection, and these drugs have shown promising antiviral activity in both cell culture and animal models. Some of these drugs are also in clinical trial for SARS-CoV-2 (Li and De Clercq 2020). In the past 2 months, drugs from various classes such as nucleoside analogs, protease inhibitors, and host-targeted agents have been tested to discover an authorized antiviral agent against SARS-CoV-2 infection (Table 10.2). The National Medical Products Administration of China has recently approved fapilavir as the first antiviral medication for the treatment of SARS-CoV-2.

\subsubsection{Approved Nucleoside Analogs}

At present, two approved nucleoside analogs (ribavirin and favipiravir) demonstrated antiviral activity against SARS-CoV-2 infection (Wang et al. 2020). Nucleoside analogs have efficacy to target RNA-dependent RNA polymerase and inhibit the replication process in a broad range of RNA viruses including beta coronaviruses. Ribavirin was originally licensed for the treatment of $\mathrm{HCV}$ (hepatitis $\mathrm{C}$ virus) and RSV (respiratory syncytial virus). Ribavirin was also clinically evaluated against MERS and SARS coronaviruses, but the efficacy of the drug is uncertain and associated with severe side effects such as anemia and hypoxia at high doses (Arabi et al. 2019). Similarly, ribavirin was also evaluated against SARS-CoV-2 infection, but the antiviral property of drugs is still not well established against the SARS-CoV-2. In addition, after oral administration, the drug was rapidly absorbed via sodium-dependent nucleoside transporters into the gastrointestinal tract. The drug has oral bioavailability around 64\% with large volume of distribution. Drugs such as acetaminophen, acetazolamide, aspirin, acrivastine, and acyclovir are known to decrease the excretion rate that leads to the higher serum level of ribavirin. 
Table 10.2 List of drugs that have antiviral activity compounds against SARS-CoV-2

\begin{tabular}{|c|c|c|}
\hline Antiviral agents & Drug targets & Reported mechanism of action \\
\hline \multicolumn{3}{|c|}{ Virus-based treatment approaches } \\
\hline Favipiravir & RdRp & Inhibits RdRp \\
\hline Ribavirin & $\operatorname{RdRp}$ & Inhibits viral RNA synthesis and mRNA capping \\
\hline Penciclovir & RdRp & Inhibits RdRp \\
\hline $\begin{array}{l}\text { Remdesivir } \\
(\mathrm{GS}-5734)\end{array}$ & $\operatorname{RdRp}$ & Terminates the non-obligate chain \\
\hline Lopinavir & 3CLpro & Inhibits 3CLpro \\
\hline Ritonavir & 3CLpro & Inhibits 3CLpro \\
\hline $\begin{array}{l}\text { Darunavir and } \\
\text { cobicistat }\end{array}$ & 3CLpro & Inhibits 3CLpro \\
\hline $\begin{array}{l}\text { ASC09F (HIV pro- } \\
\text { tease inhibitor) }\end{array}$ & 3CLpro & Inhibits 3CLpro \\
\hline Nafamostat & $\begin{array}{l}\text { Spike } \\
\text { glycoprotein }\end{array}$ & Inhibits spike-mediated membrane fusion \\
\hline Griffithsin & $\begin{array}{l}\text { Spike } \\
\text { glycoprotein }\end{array}$ & Inhibits spike-mediated membrane fusion \\
\hline $\begin{array}{l}\text { Arbidol } \\
\text { (umifenovir) }\end{array}$ & - & - \\
\hline Oseltamivir & - & - \\
\hline \multicolumn{3}{|c|}{ Host-based treatment approaches } \\
\hline $\begin{array}{l}\text { Recombinant } \\
\text { interferons }\end{array}$ & $\begin{array}{l}\text { Interferon } \\
\text { response }\end{array}$ & Exogenous interferons \\
\hline Chloroquine & $\begin{array}{l}\text { Endosomal } \\
\text { acidification }\end{array}$ & $\begin{array}{l}\text { A lysosomotropic base that appears to disrupt intracel- } \\
\text { lular trafficking and viral fusion events }\end{array}$ \\
\hline Nitazoxanide & $\begin{array}{l}\text { Interferon } \\
\text { response }\end{array}$ & $\begin{array}{l}\text { Induces the host innate immune response to produce } \\
\text { interferons by the host's fibroblasts and protein kinase R } \\
\text { (PKR) activation }\end{array}$ \\
\hline
\end{tabular}

Similarly, coadministration of abacavir may increase the hepatotoxicity of ribavirin. Favipiravir (T-705) was initially authorized for the treatment of influenza. In addition, it is reported that favipiravir is also effective against a number of RNA viruses such as Ebola, Nipah, and enterovirus. Similarly, favipiravir demonstrates efficacy against SARS-CoV-2, and currently the drug is in randomized trials with interferon$\alpha$ and baloxavir marboxil for SARS-CoV-2 infection (Li and De Clercq 2020). The drug is well absorbed after oral administration in the gastrointestinal tract $(98 \%$ bioavailability) and metabolized in liver, and the metabolites are excreted in urine. Favipiravir is contraindicated in pregnancy due to its teratogenic effect. Favipiravir also decreases the excretion of angiotensin-converting enzyme inhibitors such as captopril. 


\subsubsection{Experimental Nucleoside Analogs}

Unlike the approved nucleoside analogs, two experimental nucleoside analogs remdesivir (GS-5734) and galidesivir (BCX4430) were also investigated against SARS-CoV-2 infection. Remdesivir and Galidesivir are adenine derivatives which demonstrate broad-spectrum antiviral activity in cell cultures and animal models against RNA viruses such as MERS and SARS (Agostini et al. 2018; Sheahan et al. 2020; Warren et al. 2014). Recently, it is shown that the drug inhibited SARS-CoV-2 by integrating into nascent viral RNA chains that lead to premature termination of viral RNA chains (Wang et al. 2020). Remdesivir is presently in clinical trial for Ebola and SARS-CoV-2 infection (Li and De Clercq 2020).

\subsubsection{Approved Protease Inhibitors}

Drugs such as disulfiram, lopinavir, and ritonavir have antiviral activity against human coronaviruses. Disulfiram was primarily used for the management of alcohol dependence, and it is reported that the drug also inhibits the papain-like protease of MERS and SARS in cell line models (Agostini et al. 2018). In addition, lopinavir and ritonavir are the HIV protease inhibitors that also have efficacy against 3-chymotrypsin-like protease of MERS and SARS (Sheahan et al. 2020; Kim et al. 2016; Chan et al. 2015). However, the mechanism of action of these protease inhibitors is still controversial. At present, lopinavir and ritonavir are in clinical trial in patients infected with SARS-CoV-2, and the results demonstrate that lopinavir-ritonavir treatment fails to reduce mortality or throat viral RNA load in patients with Covid19 (Cao et al. 2020). In the same way, nafamostat and griffithsin demonstrated inhibitory activity against spike glycoprotein of coronaviruses (Wang et al. 2020; Barton et al. 2014; O’Keefe et al. 2010).

\subsubsection{Host-Targeted Strategies}

Several immune modulator drugs such as chloroquine, nitazoxanide, and ribavirin in combination of PEGylated interferon alfa- $2 a$ and $-2 b$ have shown inhibitory action against SARS-CoV-2 infection (Li and De Clercq 2020). A recent study has shown that chloroquine is more effective to prevent SARS-CoV-2 infection in cell culture model compared to other tested drugs and also in an open-label trial for the treatment of SARS-CoV-2 infection in patients (Fig. 10.1) (Wang et al. 2020). 


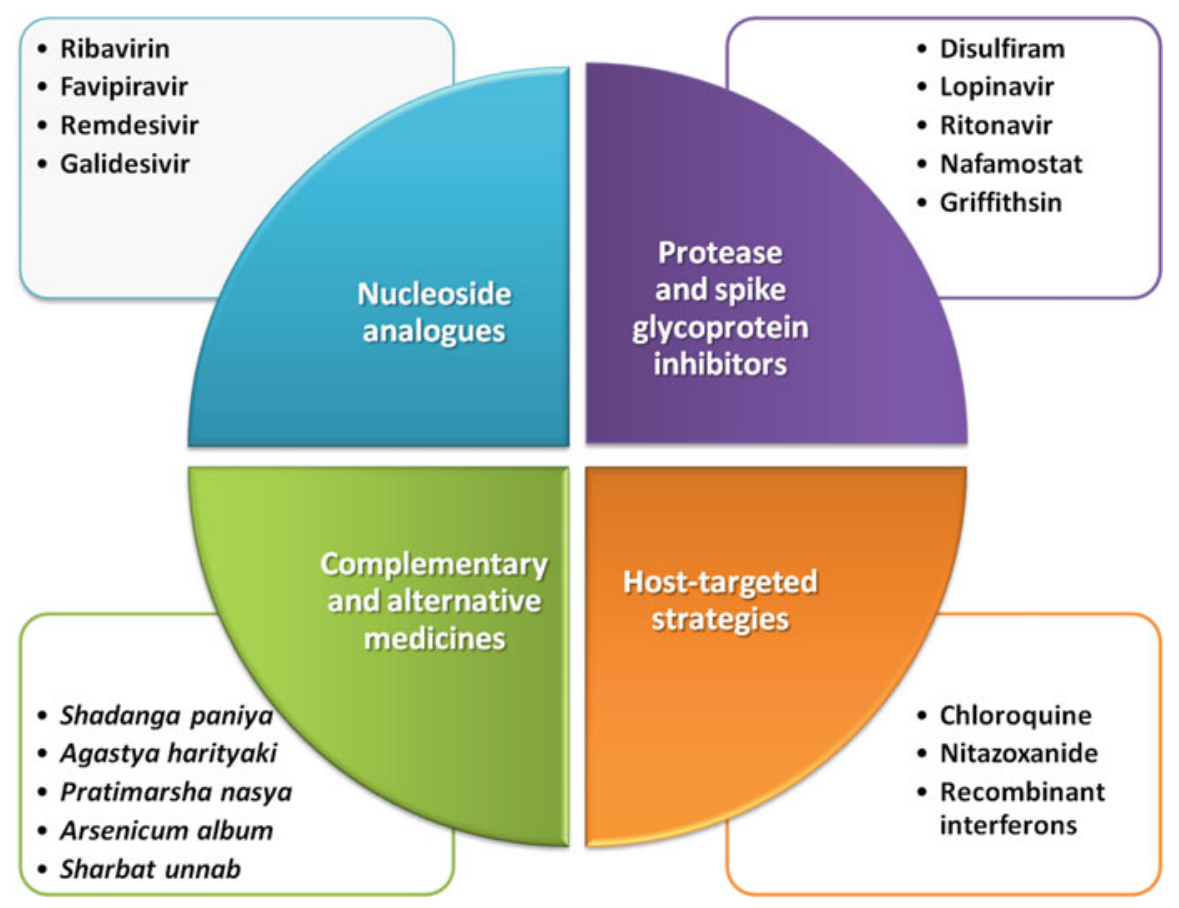

Fig. 10.1 Investigational treatment approaches for COVID-19 infection

\subsubsection{Early Supportive Therapy for SARS-CoV-2 Infection}

Patients with severe acute respiratory infection should be closely monitored for clinical signs and symptoms like sepsis and rapid respiratory failure to provide immediate supportive treatment in case of severe infection. Supplemental oxygen therapy must be provided in case of shock, hypoxemia, severe acute respiratory infection, and respiratory distress. Similarly, fluid and electrolyte balance should be maintained in infected patients. Antimicrobial agents should be given for the management of pathogen-associated severe acute respiratory infections. The administration of systemic corticosteroids should be avoided in case of viral pneumonia and patients with acute respiratory distress syndrome (World Health Organization 2020b). 


\subsection{Treatment of MERS-CoV and SARS-CoV Infections}

In view of the high mortality rate of MERS-CoV and SARS-CoV infections, there are no licensed antiviral agents or vaccines available to date for successful disease control during outbreaks (Shahani et al. 2017). Although, various therapeutic alternatives have been given for the management of infection such as antiviral drugs (ribavirin, lopinavir, and ritonavir), convalescent plasma, corticosteroids, monoclonal antibodies, intravenous immunoglobulin, and repurposing of existing clinically FDA-approved drugs (Totura and Bavari 2019). The effectiveness of these drugs is not well established and given as symptomatic treatment to control the severity of infection. However, a retrospective analysis reported that ribavirin alone or in combination with interferon-alpha (IFN-â) or lopinavir or ritonavir showed increase in survival compared to patients taking supportive care and corticosteroids against MERS-CoV infection (Falzarano et al. 2013; Chu et al. 2004; Chiou et al. 2005; Loutfy et al. 2003). In the same way, several studies have reported that ribavirin in conjugation with fluoroquinolones and corticosteroids did not demonstrate efficacy in patients with SARS-CoV infection (Table 10.3) (Al-Tawfiq et al. 2014; Omrani et al. 2014; Spanakis et al. 2014; Leong et al. 2004; Muller et al. 2007; Ward et al. 2005; Zhao et al. 2003). Nevertheless, it is concluded that ribavirin alone or in combination with other drugs fails to improve patient outcome against both MERS$\mathrm{CoV}$ and SARS-CoV infections and is associated with adverse effects such as decreased hemoglobin levels, hemolytic anemia, hypoxemia, and metabolic abnormalities. In addition to ribavirin, interferons are also associated with psychiatric disturbances, neutropenia, and systemic adverse effects (Al-Dorzi et al. 2016). Drug repurposing is an eye-catching alternative approach for discovering newer drugs during the virus epidemics for a number of viral infections because various measures are typically skipped during the initial phase of drug design. Recently, researchers have investigated the antiviral potential of various approved drugs as first-line of defense against the newly emerging infectious agents. Repurposing of pharmaceutical agents could be an effective arm to develop potential therapeutics for SARSCoV-2, MERS-CoV, and SARS-CoV infection (Dyall et al. 2017). The drugs from various classes such as antidiarrheal agents, antimalarial agents, cyclophilin inhibitors, interferons, kinase inhibitors, neurotransmitter inhibitors, anticholinergics, nucleic acid synthesis inhibitors, protease inhibitors, protein synthesis inhibitors, selective estrogen receptor modulators, and sterol metabolism inhibitors have demonstrated in vitro and in vivo antiviral efficacy against MERS-CoV and SARS-CoV infection (Table 10.4) (Dyall et al. 2014, 2017; de Wilde et al. 2011, 2014; Hart et al. 2014; Cinatl et al. 2003; Kindrachuk et al. 2015; Cheng et al. 2015; Saijo et al. 2005; Zhou et al. 2015; Cao et al. 2015). 
Table 10.3 Drug regimens used for the treatment of MERS and SARS-CoV infection

\begin{tabular}{|c|c|}
\hline Treatment & Outcome \\
\hline \multicolumn{2}{|l|}{ MERS-CoV infection } \\
\hline $\begin{array}{l}\text { Ribavirin (oral/IV) } \\
\text { IFN-ả } 2 b \\
\text { Corticosteroids }\end{array}$ & $\begin{array}{l}\text { Late treatment administration. Disease progression delayed and all } \\
\text { patients died }\end{array}$ \\
\hline $\begin{array}{l}\text { Ribavirin (oral/IV) } \\
\text { PEGylated IFN-à } \\
\text { (IV) } \\
\pm \text { Corticosteroids }\end{array}$ & $\begin{array}{l}\text { Treatment was given } 0-8 \text { days after diagnosis } \\
\text { Significant decreases in hemoglobin and absolute neutrophil count } \\
\text { (baseline count lower in treatment group) were also reported }\end{array}$ \\
\hline $\begin{array}{l}\text { Ribavirin (oral/IV) } \\
\text { Lopinavir/ritonavir } \\
\text { IFN-à-2b }\end{array}$ & $\begin{array}{l}\text { No detectable viral RNA in serum after } 2 \text { days of therapy } \\
\text { Ribavirin discontinued due to jaundice, hyperbilirubinemia } \\
\text { Patients died with septic shock in } 2 \text { months }\end{array}$ \\
\hline \multicolumn{2}{|l|}{ SARS-CoV infection } \\
\hline $\begin{array}{l}\text { Ribavirin (oral/IV) } \\
\text { Antibiotics } \\
\pm \text { Corticosteroids } \\
\pm \text { Immunoglobulin }\end{array}$ & $\begin{array}{l}\text { No increased positive outcome with ribavirin compared to controls } \\
\text { Increased risk of anemia, hypomagnesemia, hypoxia, or bradycardia with } \\
\text { ribavirin compared to ribavirin-naive patients }\end{array}$ \\
\hline $\begin{array}{l}\text { Ribavirin (oral/IV) } \\
\text { Lopinavir/ritonavir } \\
\pm \text { Corticosteroids }\end{array}$ & $\begin{array}{l}\text { Fatality or acute respiratory distress syndrome (ARDS) was reduced } \\
\text { significantly from } 28.8 \% \text { to } 2.4 \%\end{array}$ \\
\hline $\begin{array}{l}\text { IFN-alfacon-1 } \\
\pm \text { Corticosteroids } \\
\pm \text { Antibiotics }\end{array}$ & $\begin{array}{l}\text { Increased oxygen saturation } \\
\text { Increased clearance of lung abnormalities } \\
\text { Slight increase in creatinine kinase concentrations }\end{array}$ \\
\hline $\begin{array}{l}\text { Fluoroquinolone } \\
\text { (IV) } \\
\text { Azithromycin (IV) } \\
\text { IFN- } \alpha \text { (IM) } \\
\pm \text { Corticosteroids } \\
\pm \text { Immunoglobulins } \\
\pm \text { Thymic peptides/ } \\
\text { proteins }\end{array}$ & No increased positive outcome \\
\hline $\begin{array}{l}\text { Quinolone (IV) } \\
\text { Azithromycin (IV) } \\
\pm \text { IFN- } \alpha \\
\pm \text { Corticosteroids }\end{array}$ & No increased positive outcome \\
\hline $\begin{array}{l}\text { Levofloxacin } \\
\text { Azithromycin } \\
\pm \text { IFN- } \alpha \\
\pm \text { Corticosteroids }\end{array}$ & $\begin{array}{l}\text { Increased survival } \\
\text { Increased clearance of lung abnormalities }\end{array}$ \\
\hline
\end{tabular}


Table 10.4 List of drugs with in vitro and in vivo antiviral activity against MERS-CoV and SARS$\mathrm{CoV}$

\begin{tabular}{|c|c|c|}
\hline Drugs & Class & Mechanism of action \\
\hline Loperamide & $\begin{array}{l}\text { Antidiarrheal } \\
\text { agents }\end{array}$ & Unknown \\
\hline $\begin{array}{l}\text { Chloroquine, amodiaquine, } \\
\text { mefloquine }\end{array}$ & $\begin{array}{l}\text { Antimalarial } \\
\text { agents }\end{array}$ & $\begin{array}{l}\text { Chloroquine targets the type II trans- } \\
\text { membrane serine protease of MERS- } \\
\text { CoV } \\
\text { For SARS-CoV, chloroquine has also } \\
\text { been attributed to a deficit in glyco- } \\
\text { sylation of the receptor angiotensin- } \\
\text { converting enzyme } 2\end{array}$ \\
\hline Cyclosporine A & $\begin{array}{l}\text { Cyclophilin } \\
\text { inhibitors }\end{array}$ & Unknown \\
\hline 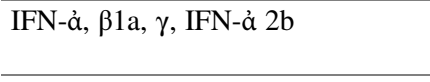 & Interferons & $\begin{array}{l}\text { Inhibits replication of MERS-CoV } \\
\text { and SARS-CoV }\end{array}$ \\
\hline $\begin{array}{l}\text { Imatinib, dasatinib, selumetinib, } \\
\text { trametinib, sirolimus }\end{array}$ & Kinase inhibitors & $\begin{array}{l}\text { Imatinib and dasatinib act as entry } \\
\text { inhibitor for both MERS and SARS } \\
\text { Selumetinib and trametinib block the } \\
\text { entry and replication of MERS-CoV } \\
\text { via targeting ERK/MAPK signaling } \\
\text { pathway. Sirolimus reduced MERS- } \\
\text { CoV infection by } ~ 60 \% \text { via targeting } \\
\text { mTOR signaling pathway }\end{array}$ \\
\hline $\begin{array}{l}\text { Chlorpromazine, triflupromazine, } \\
\text { thiethylperazine, promethazine flu- } \\
\text { phenazine, astemizole, } \\
\text { chlorphenoxamine, fluspirilene }\end{array}$ & $\begin{array}{l}\text { Neurotransmitter } \\
\text { inhibitors }\end{array}$ & $\begin{array}{l}\text { Chlorpromazine inhibits virus entry, } \\
\text { whereas antiviral mechanism of other } \\
\text { listed drugs was still not clearly } \\
\text { understood }\end{array}$ \\
\hline Benztropine & Anticholinergic & Unknown \\
\hline $\begin{array}{l}\text { Ribavirin, mycophenolic acid, } \\
\text { mizoribine, gemcitabine }\end{array}$ & $\begin{array}{l}\text { Nucleic acid syn- } \\
\text { thesis inhibitors }\end{array}$ & Unknown \\
\hline $\begin{array}{l}\text { Camostat mesylate, K11777, } \\
\text { E-64-D, lopinavir }\end{array}$ & $\begin{array}{l}\text { Protease } \\
\text { inhibitors }\end{array}$ & $\begin{array}{l}\text { Camostat mesylate inhibits } \\
\text { TMPSSR2-mediated glycoprotein } \\
\text { activation of MERS-CoV and SARS- } \\
\text { CoV. K11777 and E-64-D act as } \\
\text { attachment inhibitor for both MERS- } \\
\text { CoV and SARS-CoV. Lopinavir has } \\
\text { been shown to target the main prote- } \\
\text { ase (Mpro) of SARS-CoV }\end{array}$ \\
\hline $\begin{array}{l}\text { Emetine, anisomycin, omacetaxine } \\
\text { mepesuccinate }\end{array}$ & $\begin{array}{l}\text { Protein synthesis } \\
\text { inhibitors }\end{array}$ & Unknown \\
\hline $\begin{array}{l}\text { Toremifene citrate, tamoxifen } \\
\text { citrate }\end{array}$ & $\begin{array}{l}\text { Selective estro- } \\
\text { gen receptor } \\
\text { modulators }\end{array}$ & Unknown \\
\hline Terconazole and triparanol & $\begin{array}{l}\text { Sterol metabo- } \\
\text { lism inhibitors }\end{array}$ & Unknown \\
\hline
\end{tabular}




\subsection{Vaccine for Coronaviruses}

Currently, vaccines that can protect against $\mathrm{CoV}$ infection are not available. Recently, many groups are involved in vaccine designing using a variety of platforms against CoVs. Some of these approaches have demonstrated effectiveness in animal models. The spike (S) protein present in CoVs acts as a viral antigen and responsible for host-receptor binding and virus internalization and induces robust humoral and cell-mediated responses in humans during infection. The S glycoprotein has been shown to involve in the internalization of other CoVs like SARS by binding to its cellular receptor angiotensin-converting enzyme 2 (ACE2). The S-protein functions in the receptor binding and membrane fusion make it the ideal target for the production of vaccines against CoVs (Wang et al. 2016). Recent experiments have shown that the S-protein vaccine can trigger antibodies to resist virus binding, fusion, and neutralization of SARS-CoV infection. Recently, Sprotein-based vaccines such as DNA vaccines, modified vaccinia Ankara (MVA)based chimeric virus vaccines, subunit vaccines, and virus-like replicon particle (VRP)-based chimeric virus vaccines have been developed, and they demonstrate protective effect against both MERS-CoV and SARS-CoV infections in animal models (Schindewolf and Menachery 2019).

\subsection{Complementary and Alternative Medicines (CAM) for Coronaviruses}

According to the National Center for Complementary and Integrative Health (NCCIH) of the National Institute of Health (NIH), USA, CAM encompasses various medical methods, such as homeopathy, naturopathy, Ayurveda, medicinal systems, and products originating from traditional medicine. Recently, CAM therapies have shown to be potential therapeutics for the management of virusassociated diseases such as influenza, Japanese encephalitis, hepatitis C, zika, and HIV (Saxena et al. 2017). These medicines also demonstrate efficacy against coronaviruses with minimal reported adverse effects on host cells. Considering the global transmission and fatality rate of SARS-CoV-2 infection, the Government of India, Ministry of Ayush has given recommendations for the use of Indian herbal drugs that practices under the Ayurveda, Homeopathy, and Unani system of medicine for combating coronaviruses (PIB Delhi 2020).

\subsubsection{Ayurverdic Medicines for the Treatment of Coronaviruses}

Shadanga Paniya is a herbal formulation that mainly comprises Cyperus rotundus, Fumaria indica, Vetiveria zizanioides, Pterocarpus santalinus, Pavonia odorata, 
and Zingiber officinale). This herbal formulation is recommended for the treatment of symptoms such as high fever, shivering, muscle aches, headache, loss of appetite, dehydration, fatigue, restlessness, excessive thirst, irritability, and burning sensation. In addition, Shadanga Paniya also has antibacterial and antimicrobial activities, and recently, this medicine is recommended by the Ministry of Ayush for the treatment of coronaviruses. Agastya Harityaki is a popular polyherbal Ayurverdic medicine mainly recommended for respiratory problems such as asthma, pneumonia, and chronic bronchitis. The medicine is reported to have antiviral, antibacterial, antifungal, antioxidant, anticarcinogenic, antiaging, antidiabetic, antiulcer, cardioprotective, hepatoprotective, and wound healing properties. Samshamani Vati is used for the treatment of acute to chronic fever and anemia (500 mg twice a day). Tinospora cordifolia is the main ingredient and responsible for antiinflammatory and antipyretic properties of Samshamani Vati. Pratimarsha Nasya (Anu taila/sesame oil) has preventive as well as curative aspect for the treatment of Nasobronchial diseases and enhances the respiratory immunity. The ingredients present in sesame oil are well known for anti-inflammatory, antipyretic, and antibacterial proprieties. Another formulation which comprises Trikatu (Pippali, Marich, and Shunthi) and Tulasi is also recommended by the Ministry of Ayush for the treatment of coronavirus infection in India.

\subsubsection{Homeopathic Medicines for the Treatment of Coronaviruses}

After the emergence of SARS-CoV-2 in India, the Central Council for Research in Homeopathy $(\mathrm{CCRH})$ has recommended Arsenicum Album 30 as prophylactic medicine against coronavirus infections. It was recommended that one dose of Arsenicum Album 30 should be given daily in empty stomach for 3 days and should be replicated after 1 month on the same schedule in the case of coronavirus infections arising in the population.

\subsubsection{Unani Medicines for the Treatment of Coronaviruses}

The Government of India has suggested a number of Unani medicines such as Sharbat Unnab (10-20 ml), TiryaqArba (3-5 g), TiryaqNazla (5 g), Habb e IkseerBukhar (2 pills), Sharbat Nazla $(10 \mathrm{ml})$, and Qurs e Suaal (2 tablets) recommended twice a day with lukewarm water. In addition, Arq Ajeeb (4-8 drops) and Khamira Marwareed (3-5 g) are also suggested for the better management of disease. Similarly, medicines like RoghanBaboona/Roghan Mom/Kafoori Balm are also recommended for massage on scalp and chest in case of infection. In addition, the Arq extracted from single Unani drugs like Azadirachta indica (Margosa), Swertiachirata karst (Indian Gentian), Trachyspermum ammi sprague 
(ajowan), Cichorium intybus Linn. (common chicory), Cyperus scariosus R. Br. (cypriol), Borage officinalis Linn. (Borage), and Artemisia absinthium Linn. (common sagewort) along with SharbatKhaksi may be used to combat the infection. In the same way, decoction of Unani drugs such as Cydonia oblonga (Quince), Zizyphus Jujube Linn. (jujubi), Papaver somniferum (khashkhash), Cordia myxa Linn. (Assyrian plum), Cinnamomum zeylanicum (cinnamon), Hyoscyamus niger (bazrulbanj), Viola odorata Linn. (sweet violet), Borago Officinalis Linn. (borage), Myrtus communis (Barg e Moard), Lactuca sativa (Tukhm e kahuMukashar), and Rosa damascene (GuleSurkh) are also being suggested for conditions like sore throat during infection.

\subsubsection{Herbal Medicines Showing Efficacy Against Coronavirus in Cell Culture Model}

It is reported that a number of herbal extract of Anthemis hyaline, Acanthopanacis cortex, Citrus sinensis, Sophorae radix, Sanguisorbae radix, Nigella sativa, and Torilis fructus inhibit coronavirus replication in vitro (Ulasli et al. 2014; Kim et al. 2010). Similarly, studies have demonstrated that traditionally used medicinal herbal extracts such as Cimicifuga rhizoma, Coptidis rhizoma, Phellodendron cortex, and Meliae cortex are also shown to inhibit $\mathrm{CoV}$ replication in cell culture model (Kim et al. 2008). Emodin, a chemical constituent of genus Rheum, and Polygonum are also shown to block the binding of SARS-CoV S-protein to ACE2 in a dosedependent manner (Ho et al. 2007). In the same manner, Artemisia annua, Lycoris radiate, Lindera aggregata, lycorine, and Pyrrosia lingua also showed antiviral activity against SARS-CoV ( $\mathrm{Li}$ et al. 2005). In addition, saikosaponins are natural triterpene glycosides $\left(A, B_{2}, C\right.$, and $\left.D\right)$ and were tested against $\mathrm{HCoV}-22 \mathrm{E}$, and it is found that saikosaponin $\mathrm{B}_{2}$ inhibits virus attachment and penetration stage to the host cells (Cheng et al. 2006). In the same way, myricetin and scutellarein act as inhibitor of SARS-CoV helicase. Similarly, theaflavin-3,3-digallate (TF3) is a natural polyphenolic compound and demonstrates antiviral activity via targeting 3C-like proteases of SARS-CoV (Chen et al. 2005). Eupatorium fortune is a herbal medicinal plant belonging to Korea, China, and Asian countries with antibacterial and antioxidant activities and anticancer activity. Recent studies have reported that eupatorium fortune can inhibit a number of RNA viruses including human coronaviruses (Choi et al. 2017). As these herbal drugs demonstrated potential antiviral activity against $\mathrm{CoVs}$, there is an urgent need to establish their effectiveness in humans and approve in a dose-dependent manner from various organizations like Food and Drug Administration (FDA). In the absence of specific antiviral agent or vaccine, the use of complementary and alternative drugs may found to be beneficial during humanitarian emergencies. 


\subsection{Conclusions}

The recent outbreak brought SARS-CoV-2 as global concern and emphasizes the significance of restricting infectious agents at international borders. The risk of SARS-CoV-2 outbreaks depends on the characteristics of the virus, including the ability of the virus to transmit among humans, the seriousness of the disease, and the medical or other interventions available to prevent the transmission of virus, such as vaccines or drugs. Although, ribavirin along with corticosteroids and interferons has been tested in patients with SARS and MARS-CoV infections, but the effectiveness and associated severe adverse effects of this regimen is still not yet confirmed. In addition, a large number of drugs from different classes have been used for the management of symptoms associated with the infection and reported to have antiviral activity against both SARS and MARS-CoV infections in animal and cell culture model. However, the antiviral potential of these repurposing drugs are need to be validated in clinical trials in order to developed broad-spectrum therapy for SARS-CoV-2, SARS-CoV, and MARS-CoV infections.

\subsection{Future Perspectives}

At present, the control of viral spread is critical in order to restrict the transmission of infection. The effective communication among the various organizations such as government, industry, academic, national, and international bodies is crucial in order to prevent the transmission of infection during outbreaks. In the absence of specific therapeutic agent, the study of pathogenesis of infection is imperative to identify newer targets for designing of novel therapeutic agents for future outbreaks. Similarly, the standardization of various complementary and alternative medicines may prove as safe and potential therapeutic strategies for emerging CoVs.

Acknowledgements and Disclosures The authors are grateful to the Vice Chancellor, King George's Medical University (KGMU), Lucknow, India for the encouragement for this work. The authors have no other relevant affiliations or financial involvement with any organization or entity with a financial interest in or financial conflict with the subject matter or materials discussed in the manuscript apart from those disclosed.

Financial support: None.

Conflict of interest: The authors declare no conflict of interest.

\section{References}

Agostini ML, Andres EL, Sims AC, Graham RL, Sheahan TP, Lu X, Smith EC, Case JB, Feng JY, Jordan R, Ray AS, Cihlar T, Siegel D, Mackman RL, Clarke MO, Baric RS, Denison MR (2018) Coronavirus susceptibility to the antiviral Remdesivir (GS-5734) is mediated by the viral polymerase and the proofreading Exoribonuclease. MBio 9(2). pii: e00221-18. https://doi.org/ 10.1128/mBio.00221-18 
Al-Dorzi HM, Alsolamy S, Arabi YM (2016) Critically ill patients with Middle East respiratory syndrome coronavirus infection. Crit Care 20:65. https://doi.org/10.1186/s13054-016-1234-4

Al-Tawfiq JA, Momattin H, Dib J, Memish ZA (2014) Ribavirin and interferon therapy in patients infected with the Middle East respiratory syndrome coronavirus: an observational study. Int $\mathbf{J}$ Infect Dis 20:42-46. https://doi.org/10.1016/j.ijid.2013.12.003

Andersen KG, Rambaut A, Lipkin WI, Holmes EC, Garry RF (2020) The proximal origin of SARSCoV-2. Nat Med:1-3. https://doi.org/10.1038/s41591-020-0820-9

Arabi YM, Arifi AA, Balkhy HH, Najm H, Aldawood AS, Ghabashi A, Hawa H, Alothman A, Khaldi A, Al Raiy B (2014) Clinical course and outcomes of critically ill patients with Middle East respiratory syndrome coronavirus infection. Ann Intern Med 160(6):389-397. https://doi. org/10.7326/M13-2486

Arabi YM, Shalhoub S, Mandourah Y, Al-Hameed F, Al-Omari A, Al Qasim E, Jose J, Alraddadi B, Almotairi A, Al Khatib K, Abdulmomen A, Qushmaq I, Sindi AA, Mady A, Solaiman O, Al-Raddadi R, Maghrabi K, Ragab A, Al Mekhlafi GA, Balkhy HH, Al Harthy A, Kharaba A, Gramish JA, Al-Aithan AM, Al-Dawood A, Merson L, Hayden FG, Fowler R (2019. pii: ciz544. [Epub ahead of print]) Ribavirin and Interferon therapy for critically ill patients with Middle East Respiratory Syndrome: a multicenter observational study. Clin Infect Dis. https://doi.org/10.1093/cid/ciz544

Barton C, Kouokam JC, Lasnik AB, Foreman O, Cambon A, Brock G, Montefiori DC, Vojdani F, McCormick AA, O'Keefe BR, Palmer KE (2014) Activity of and effect of subcutaneous treatment with the broad-spectrum antiviral lectin griffithsin in two laboratory rodent models. Antimicrob Agents Chemother 58(1):120-127. https://doi.org/10.1128/AAC.01407-13

Cao J, Forrest JC, Zhang X (2015) A screen of the NIH clinical collection small molecule library identifies potential anti-coronavirus drugs. Antivir Res 114:1-10. https://doi.org/10.1016/j. antiviral.2014.11.010

Cao B, Wang Y, Wen D, Liu W, Wang J, Fan G, Ruan L, Song B, Cai Y, Wei M, Li X, Xia J, Chen N, Xiang J, Yu T, Bai T, Xie X, Zhang L, Li C, Yuan Y, Chen H, Li H, Huang H, Tu S, Gong F, Liu Y, Wei Y, Dong C, Zhou F, Gu X, Xu J, Liu Z, Zhang Y, Li H, Shang L, Wang K, Li K, Zhou X, Dong X, Qu Z, Lu S, Hu X, Ruan S, Luo S, Wu J, Peng L, Cheng F, Pan L, Zou J, Jia C, Wang J, Liu X, Wang S, Wu X, Ge Q, He J, Zhan H, Qiu F, Guo L, Huang C, Jaki T, Hayden FG, Horby PW, Zhang D, Wang C (2020) A trial of Lopinavir-Ritonavir in adults hospitalized with severe Covid-19. N Engl J Med. https://doi.org/10.1056/NEJMoa2001282

Centers for Diseases Control and Prevention (CDC) (2020). https://www.cdc.gov/coronavirus/ 2019-ncov/about/transmission.html. Accessed 15 Mar 2020

Chan JF, Yao Y, Yeung ML, Deng W, Bao L, Jia L, Li F, Xiao C, Gao H, Yu P, Cai JP, Chu H, Zhou J, Chen H, Qin C, Yuen KY (2015) Treatment with Lopinavir/Ritonavir or Interferon- $\beta 1 \mathrm{~b}$ improves outcome of MERS-CoV infection in a nonhuman primate model of common marmoset. J Infect Dis 212(12):1904-1913. https://doi.org/10.1093/infdis/jiv392

Chen CN, Lin CP, Huang KK, Chen WC, Hsieh HP, Liang PH, Hsu JT (2005) Inhibition of SARSCoV 3C-like protease activity by theaflavin-3,3'-digallate (TF3). Evid Based Complement Alternat Med 2(2):209-215

Chen N, Zhou M, Dong X, Qu J, Gong F, Han Y, Qiu Y, Wang J, Liu Y, Wei Y, Xia J, Yu T, Zhang X, Zhang L (2020) Epidemiological and clinical characteristics of 99 cases of 2019 novel coronavirus pneumonia in Wuhan, China: a descriptive study. Lancet 395(10223):507-513. . pii: S0140-6736(20)30211-7. https://doi.org/10.1016/S0140-6736(20)30211-7

Cheng PW, Ng LT, Chiang LC, Lin CC (2006) Antiviral effects of saikosaponins on human coronavirus 229E in vitro. Clin Exp Pharmacol Physiol 33(7):612-616

Cheng KW, Cheng SC, Chen WY, Lin MH, Chuang SJ, Cheng IH, Sun CY, Chou CY (2015) Thiopurine analogs and mycophenolic acid synergistically inhibit the papain-like protease of Middle East respiratory syndrome coronavirus. Antivir Res 115:9-16. https://doi.org/10.1016/j. antiviral.2014.12.011

Chiou HE, Liu CL, Buttrey MJ, Kuo HP, Liu HW, Kuo HT, Lu YT (2005) Adverse effects of ribavirin and outcome in severe acute respiratory syndrome: experience in two medical centers. Chest 128(1):263-272 
Choi JG, Lee H, Hwang YH, Lee JS, Cho WK, Ma JY (2017) Eupatorium fortunei and its components increase antiviral immune responses against RNA viruses. Front Pharmacol 8:511. https://doi.org/10.3389/fphar.2017.00511

Chu CM, Cheng VC, Hung IF, Wong MM, Chan KH, Chan KS, Kao RY, Poon LL, Wong CL, Guan Y, Peiris JS, Yuen KY, HKU/UCH SARS Study Group (2004) Role of lopinavir/ritonavir in the treatment of SARS: initial virological and clinical findings. Thorax 59(3):252-256

Cinatl J, Morgenstern B, Bauer G, Chandra P, Rabenau H, Doerr HW (2003) Treatment of SARS with human interferons. Lancet 362(9380):293-294

Dyall J, Coleman CM, Hart BJ, Venkataraman T, Holbrook MR, Kindrachuk J, Johnson RF, Olinger GG Jr, Jahrling PB, Laidlaw M, Johansen LM, Lear-Rooney CM, Glass PJ, Hensley LE, Frieman MB (2014) Repurposing of clinically developed drugs for treatment of Middle East respiratory syndrome coronavirus infection. Antimicrob Agents Chemother 58(8):4885-4893. https://doi.org/10.1128/AAC.03036-14

Dyall J, Gross R, Kindrachuk J, Johnson RF, Olinger GG Jr, Hensley LE, Frieman MB, Jahrling PB (2017) Middle East Respiratory Syndrome and Severe Acute Respiratory Syndrome: current therapeutic options and potential targets for novel therapies. Drugs 77(18):1935-1966. https:// doi.org/10.1007/s40265-017-0830-1

Falzarano D, de Wit E, Rasmussen AL, Feldmann F, Okumura A, Scott DP, Brining D, Bushmaker T, Martellaro C, Baseler L, Benecke AG, Katze MG, Munster VJ, Feldmann H (2013) Treatment with interferon- $\alpha 2 b$ and ribavirin improves outcome in MERS-CoV-infected rhesus macaques. Nat Med 19(10):1313-1317. https://doi.org/10.1038/nm.3362

Hart BJ, Dyall J, Postnikova E, Zhou H, Kindrachuk J, Johnson RF, Olinger GG Jr, Frieman MB, Holbrook MR, Jahrling PB, Hensley L (2014) Interferon- $\beta$ and mycophenolic acid are potent inhibitors of Middle East respiratory syndrome coronavirus in cell-based assays. J Gen Virol 95 (Pt 3):571-577. https://doi.org/10.1099/vir.0.061911-0

Ho TY, Wu SL, Chen JC, Li CC, Hsiang CY (2007) Emodin blocks the SARS coronavirus spike protein and angiotensin-converting enzyme 2 interaction. Antivir Res 74(2):92-101

Huang C, Wang Y, Li X, Ren L, Zhao J, Hu Y, Zhang L, Fan G, Xu J, Gu X, Cheng Z, Yu T, Xia J, Wei Y, Wu W, Xie X, Yin W, Li H, Liu M, Xiao Y, Gao H, Guo L, Xie J, Wang G, Jiang R, Gao Z, Jin Q, Wang J, Cao B (2020) Clinical features of patients infected with 2019 novel coronavirus in Wuhan, China. Lancet 395(10223):497-506. pii: S0140-6736(20)30183-5. https://doi.org/10.1016/S0140-6736(20)30183-5

Hui DSC, Zumla A (2019) Severe Acute Respiratory Syndrome: historical, epidemiologic, and clinical features. Infect Dis Clin North Am 33(4):869-889. https://doi.org/10.1016/j.idc.2019. 07.001

Kim HY, Shin HS, Park H, Kim YC, Yun YG, Park S, Shin HJ, Kim K (2008) In vitro inhibition of coronavirus replications by the traditionally used medicinal herbal extracts, Cimicifuga rhizoma, Meliae cortex, Coptidis rhizoma, and Phellodendron cortex. J Clin Virol 41(2):122-128

Kim HY, Eo EY, Park H, Kim YC, Park S, Shin HJ, Kim K (2010) Medicinal herbal extracts of Sophorae radix, Acanthopanacis cortex, Sanguisorbae radix and Torilis fructus inhibit coronavirus replication in vitro. Antivir Ther 15(5):697-709. https://doi.org/10.3851/IMP1615

Kim UJ, Won EJ, Kee SJ, Jung SI, Jang HC (2016) Combination therapy with lopinavir/ritonavir, ribavirin and interferon- $\alpha$ for Middle East respiratory syndrome. Antivir Ther 21(5):455-459. https://doi.org/10.3851/IMP3002

Kindrachuk J, Ork B, Hart BJ, Mazur S, Holbrook MR, Frieman MB, Traynor D, Johnson RF, Dyall J, Kuhn JH, Olinger GG, Hensley LE, Jahrling PB (2015) Antiviral potential of ERK/MAPK and PI3K/AKT/mTOR signaling modulation for Middle East respiratory syndrome coronavirus infection as identified by temporal kinome analysis. Antimicrob Agents Chemother 59(2):1088-1099. https://doi.org/10.1128/AAC.03659-14

Kumar S, Maurya VK, Prasad AK, Bhatt ML, Saxena SK (2020) Structural, glycosylation and antigenic variation between 2019 novel coronavirus $(2019-\mathrm{nCoV})$ and SARS coronavirus (SARS-CoV). Virus Dis:1-9. https://doi.org/10.1007/s13337-020-00571-5

Leong HN, Ang B, Earnest A, Teoh C, Xu W, Leo YS (2004) Investigational use of ribavirin in the treatment of severe acute respiratory syndrome, Singapore, 2003. Tropical Med Int Health 9 (8):923-927 
Li G, De Clercq E (2020) Therapeutic options for the 2019 novel coronavirus (2019-nCoV). Nat Rev Drug Discov. https://doi.org/10.1038/d41573-020-00016-0

Li SY, Chen C, Zhang HQ, Guo HY, Wang H, Wang L, Zhang X, Hua SN, Yu J, Xiao PG, Li RS, Tan X (2005) Identification of natural compounds with antiviral activities against SARSassociated coronavirus. Antivir Res 67(1):18-23

Li Q, Guan X, Wu P, Wang X, Zhou L, Tong Y, Ren R, Leung KSM, Lau EHY, Wong JY, Xing X, Xiang N, Wu Y, Li C, Chen Q, Li D, Liu T, Zhao J, Li M, Tu W, Chen C, Jin L, Yang R, Wang Q, Zhou S, Wang R, Liu H, Luo Y, Liu Y, Shao G, Li H, Tao Z, Yang Y, Deng Z, Liu B, Ma Z, Zhang Y, Shi G, Lam TTY, Wu JTK, Gao GF, Cowling BJ, Yang B, Leung GM, Feng Z (2020) Early transmission dynamics in Wuhan, China, of novel coronavirus-infected pneumonia. N Engl J Med 382:1199-1207. https://doi.org/10.1056/NEJMoa2001316

Loutfy MR, Blatt LM, Siminovitch KA, Ward S, Wolff B, Lho H, Pham DH, Deif H, LaMere EA, Chang M, Kain KC, Farcas GA, Ferguson P, Latchford M, Levy G, Dennis JW, Lai EK, Fish EN (2003) Interferon alfacon-1 plus corticosteroids in severe acute respiratory syndrome: a preliminary study. JAMA 290(24):3222-3228

Muller MP, Dresser L, Raboud J, McGeer A, Rea E, Richardson SE, Mazzulli T, Loeb M, Louie M, Canadian SARS Research Network (2007) Adverse events associated with high-dose ribavirin: evidence from the Toronto outbreak of severe acute respiratory syndrome. Pharmacotherapy 27 (4):494-503

O'Keefe BR, Giomarelli B, Barnard DL, Shenoy SR, Chan PK, McMahon JB, Palmer KE, Barnett BW, Meyerholz DK, Wohlford-Lenane CL, McCray PB Jr (2010) Broad-spectrum in vitro activity and in vivo efficacy of the antiviral protein griffithsin against emerging viruses of the family Coronaviridae. J Virol 84(5):2511-2521. https://doi.org/10.1128/JVI.02322-09

Omrani AS, Saad MM, Baig K, Bahloul A, Abdul-Matin M, Alaidaroos AY, Almakhlafi GA, Albarrak MM, Memish ZA, Albarrak AM (2014) Ribavirin and interferon alfa-2a for severe Middle East respiratory syndrome coronavirus infection: a retrospective cohort study. Lancet Infect Dis 14(11):1090-1095. https://doi.org/10.1016/S1473-3099(14)70920-X

Paules CI, Marston HD, Fauci AS (2020) Coronavirus infections-more than just the common cold. JAMA. https://doi.org/10.1001/jama.2020.0757. [Epub ahead of print]

PIB Delhi (2020) Advisory for corona virus. Homoeopathy for prevention of corona virus Infections. unani medicines useful in symptomatic management of corona virus infection. Posted on: 29 Jan 2020 10:29 AM by PIB Delhi. https://pib.gov.in/PressReleasePage.aspx?PRID=1600895

ProMED-mail (2020) Novel coronavirus (32): China, global, case management, research. https:// promedmail.org/. Accessed 20 Mar 2020

Rasmussen SA, Watson AK, Swerdlow DL (2016) Middle East Respiratory Syndrome (MERS). Microbiol Spectr 4(3). https://doi.org/10.1128/microbiolspec.EI10-0020-2016

Saijo M, Morikawa S, Fukushi S, Mizutani T, Hasegawa H, Nagata N, Iwata N, Kurane I (2005) Inhibitory effect of mizoribine and ribavirin on the replication of severe acute respiratory syndrome (SARS)-associated coronavirus. Antivir Res 66(2-3):159-163

Saxena SK, Haikerwal A, Gadugu S, Bhatt ML (2017) Complementary and alternative medicine in alliance with conventional medicine for dengue therapeutics and prevention. Future Virol 12 (8):399-402. https://doi.org/10.2217/fvl-2017-0047

Schindewolf C, Menachery VD (2019) Middle East respiratory syndrome vaccine candidates: cautious optimism. Viruses 11(1). pii: E74. https://doi.org/10.3390/v11010074

Shahani L, Ariza-Heredia EJ, Chemaly RF (2017) Antiviral therapy for respiratory viral infections in immunocompromised patients. Expert Rev Anti-Infect Ther 15(4):401-415. https://doi.org/ 10.1080/14787210.2017.1279970

Sheahan TP, Sims AC, Leist SR, Schäfer A, Won J, Brown AJ, Montgomery SA, Hogg A, Babusis D, Clarke MO, Spahn JE, Bauer L, Sellers S, Porter D, Feng JY, Cihlar T, Jordan R, Denison MR, Baric RS (2020) Comparative therapeutic efficacy of Remdesivir and combination lopinavir, ritonavir, and interferon beta against MERS-CoV. Nat Commun 11(1):222. https:// doi.org/10.1038/s41467-019-13940-6

Shehata MM, Gomaa MR, Ali MA, Kayali G (2016) Middle East respiratory syndrome coronavirus: a comprehensive review. Front Med 10(2):120-136. https://doi.org/10.1007/s11684-0160430-6 
Skariyachan S, Challapilli SB, Packirisamy S, Kumargowda ST, Sridhar VS (2019) Recent aspects on the pathogenesis mechanism, animal models and novel therapeutic interventions for Middle East respiratory syndrome coronavirus infections. Front Microbiol 10:569. https://doi.org/10. 3389/fmicb.2019.00569

Song Z, Xu Y, Bao L, Zhang L, Yu P, Qu Y, Zhu H, Zhao W, Han Y, Qin C (2019) From SARS to MERS, thrusting coronaviruses into the spotlight. Viruses 11(1). pii: E59. https://doi.org/10. 3390/v11010059

Spanakis N, Tsiodras S, Haagmans BL, Raj VS, Pontikis K, Koutsoukou A, Koulouris NG, Osterhaus AD, Koopmans MP, Tsakris A (2014) Virological and serological analysis of a recent Middle East respiratory syndrome coronavirus infection case on a triple combination antiviral regimen. Int $\mathrm{J}$ Antimicrob Agents 44(6):528-532. https://doi.org/10.1016/j.ijantimicag.2014.07.026

Totura AL, Bavari S (2019) Broad-spectrum coronavirus antiviral drug discovery. Expert Opin Drug Discov 14(4):397-412. https://doi.org/10.1080/17460441.2019.1581171

Ulasli M, Gurses SA, Bayraktar R, Yumrutas O, Oztuzcu S, Igci M, Igci YZ, Cakmak EA, Arslan A (2014) The effects of Nigella sativa (Ns), Anthemis hyalina (Ah) and Citrus sinensis (Cs) extracts on the replication of coronavirus and the expression of TRP genes family. Mol Biol Rep 41(3):1703-1711. https://doi.org/10.1007/s11033-014-3019-7

Wang Q, Wong G, Lu G, Yan J, Gao GF (2016) MERS-CoV spike protein: targets for vaccines and therapeutics. Antivir Res 133:165-177. https://doi.org/10.1016/j.antiviral.2016.07.015

Wang M, Cao R, Zhang L, Yang X, Liu J, Xu M, Shi Z, Hu Z, Zhong W, Xiao G (2020) Remdesivir and chloroquine effectively inhibit the recently emerged novel coronavirus (2019-nCoV) in vitro. Cell Res. https://doi.org/10.1038/s41422-020-0282-0. [Epub ahead of print]

Ward SE, Loutfy MR, Blatt LM, Siminovitch KA, Chen J, Hinek A, Wolff B, Pham DH, Deif H, LaMere EA, Kain KC, Farcas GA, Ferguson P, Latchford M, Levy G, Fung L, Dennis JW, Lai EK, Fish EN (2005) Dynamic changes in clinical features and cytokine/chemokine responses in SARS patients treated with interferon alfacon-1 plus corticosteroids. Antivir Ther 10 (2):263-275

Warren TK, Wells J, Panchal RG, Stuthman KS, Garza NL, Van Tongeren SA, Dong L, Retterer CJ, Eaton BP, Pegoraro G, Honnold S, Bantia S, Kotian P, Chen X, Taubenheim BR, Welch LS, Minning DM, Babu YS, Sheridan WP, Bavari S (2014) Protection against filovirus diseases by a novel broad-spectrum nucleoside analogue BCX4430. Nature 508(7496):402-405. https://doi. org/10.1038/nature13027

de Wilde AH, Zevenhoven-Dobbe JC, van der Meer Y, Thiel V, Narayanan K, Makino S, Snijder EJ, van Hemert MJ (2011) Cyclosporin A inhibits the replication of diverse coronaviruses. J Gen Virol 92(Pt 11):2542-2548. https://doi.org/10.1099/vir.0.034983-0

de Wilde AH, Jochmans D, Posthuma CC, Zevenhoven-Dobbe JC, van Nieuwkoop S, Bestebroer TM, van den Hoogen BG, Neyts J, Snijder EJ (2014) Screening of an FDA-approved compound library identifies four small-molecule inhibitors of Middle East respiratory syndrome coronavirus replication in cell culture. Antimicrob Agents Chemother 58(8):4875-4884. https://doi.org/ 10.1128/AAC.03011-14

World Health Organization (2020a) Novel Coronavirus (2019-nCoV) situation report-14. https:// www.who.int/docs/default-source/coronaviruse/situationreports/20200203-sitrep-14-ncov.pdf. Accessed 3 Feb 2020

World Health Organization (2020b) Clinical management of severe acute respiratory infection when novel coronavirus (nCoV) infection is suspected. Interim guidance. 12 Jan 2020

Zhao Z, Zhang F, Xu M, Huang K, Zhong W, Cai W, Yin Z, Huang S, Deng Z, Wei M, Xiong J, Hawkey PM (2003) Description and clinical treatment of an early outbreak of severe acute respiratory syndrome (SARS) in Guangzhou, PR China. J Med Microbiol 52(Pt 8):715-720

Zheng J, Hassan S, Alagaili AN, Alshukairi AN, Amor NMS, Mukhtar N, Nazeer IM, Tahir Z, Akhter N, Perlman S, Yaqub T (2019) Middle East Respiratory syndrome coronavirus seropositivity in Camel handlers and their families, Pakistan. Emerg Infect Dis 25(12). https://doi.org/ 10.3201/eid2512.191169

Zhou Y, Vedantham P, Lu K, Agudelo J, Carrion R Jr, Nunneley JW, Barnard D, Pöhlmann S, McKerrow JH, Renslo AR, Simmons G (2015) Protease inhibitors targeting coronavirus and filovirus entry. Antivir Res 116:76-84. https://doi.org/10.1016/j.antiviral.2015.01.011 